\title{
The Scientific Training Programs for College Dance Students
}

\author{
Rui Huang \\ School of Music and Performance Art, Sichuan University of Science and Arts, Dazhou, China \\ Email: jjswendy@163.com
}

How to cite this paper: Huang, R. (2019) The Scientific Training Programs for College Dance Students. Open Journal of Social Sciences, 7, 233-239.

https://doi.org/10.4236/jss.2019.75020

Received: April 15, 2019

Accepted: May 24, 2019

Published: May 27, 2019

Copyright $\odot 2019$ by author(s) and Scientific Research Publishing Inc. This work is licensed under the Creative Commons Attribution International License (CC BY 4.0).

http://creativecommons.org/licenses/by/4.0/

\begin{abstract}
Contemporary society is an all-round development society which demands for more diversified talents. In the process of social development, there gradually emerged many new industries which require more talents. There are many excellent talent models in various industries. This article mainly discusses the talent demand of dance industry from the current situation of dance talents training in universities, how the dance talents adapt to society and so on. The focus of this paper is how the dance talents trained in universities become the industry standard. When social development requires both speed and quality, the construction of social spiritual civilization also needs a large number of talents for dance performance. It is necessary to make appropriate training programs according to the current situation during the course to improve the comprehensive quality of students. Through updating practical teaching methods, establishing excellent courses and guaranteeing the quality of education, universities can ultimately meet society needs for dance talents.
\end{abstract}

\section{Keywords}

Programs of Talent Training, Comprehensive Quality, Quality, Talent

Demand

\section{Introduction}

With the continuous development of national cultural and artistic undertakings, the people's demands for cultural life are constantly increasing, and the demand for high-level dance talents in the cultural market is also increasing. But university dance major in our country lacks comprehensive talents; therefore the demand exceeds the supply. In addition, higher education didn't pay attention to dance education until recent years which started slowly, so it is necessary for 
colleges and universities to speed up the pace of reform and innovation. In the current stage of development, dance performance professionals also need to better position their careers. In the latest education plan issued by the Ministry of Education, the key is "service" and "implementation". This is also the requirement for dance performance professionals. The talent training program should be made scientifically and considering the two aspects. According to these analyses, it is imperative to carry on talent training mode of dance.

\section{The Goal of the Scientific Training Programs for College Dance Students}

The main purpose of teaching dance in colleges and universities is to enable students to master basic theories, basic knowledge and general dance skills, as well as the skills of dance performances and choreographers. And we also need students to have a certain comprehensive quality so that the students can enter the special dance department to engage in key work.

The teachers of dance major should make sure that the students accept practical teaching on the basis of theory [1]. On the one hand, students need to own high-quality professional skills to adapt to the continuous development and renewal of professional art groups. On the other hand, it is also necessary to adapt to the needs of cultural undertakings and the development of cultural industries, to face the present basic performing groups, and to train talents with the ability to apply to the industry. At the same time, students need to bring into play the knowledge they have learned through their own creative dance works and by participating in various competitions, so as to ensure that the students can apply the knowledge they have learned into practice. Ensure that students can constantly create excellent dance works and display them to the society.

\section{Improving the Quality of Dance Teachers}

With the influence of 18th National Congress of Communist Party of China, a comprehensive reform and deeper development have taken place in the education during this new period. In order to improve the quality of dance teachers, colleges should understand the spirit of the Congress and get the new ideas for the educational development and new requirements for teachers quality mentioned in the 18th National Congress. Only after understanding these contents can we better improve the quality of the teachers.

Colleges should give priority to strengthen the teachers' moral education in their construction of the dance teachers, which means enhance teachers' senses of responsibility for students and their own moral qualities and put the theory into the practical teaching. Teachers should adheres to the students-oriented educational principles, carry out the principles of "From the students, to the students" and implement the principles of students-based and focus on the overall development of students and become outstanding teachers who are respected by the students and public. 
Also, colleges should pay more attention to enhancing their teaching skills in such construction and make sure that teachers can promote their ability of using of science and technology, so that teachers can implement their teaching tasks and innovate teaching methods with high quality of teaching. Teachers should make full use of science and technology to record outstanding works to help dance students learn from the outstanding works, gaining more inspiration and materials in dance creating, so that they can produce more excellent personal works and enhance their abilities. Teachers also need to help students collect good ideas and the same ground of related majors to improve their professional and practical performance ability.

In addition, dance teachers should constantly improve their professional ability to avoid self-contained situation. Schools need to arrange regular exchanges between dance teachers in various schools on student issues, so that teachers can learn from the excellent experience of other teachers in the exchange, and constantly improve their ability. Secondly, the school also needs to let teachers exchange their own knowledge with students regularly so as to enhance the communication between teachers and students so as to avoid problems that students cannot solve in time. Schools also need to have teachers perform regularly in the form of dance performances, so that teachers can increase their ability to perform to a certain extent, and students can learn more from teachers' performances. Teachers will also improve their ability in the course of preparing for the performance, which will promote the teachers' demonstration and performance in the classroom.

\section{Improve the Comprehensive Quality of Dance Students}

The best way to improve the comprehensive quality of dance students is to allow students to continuously learn and appreciate more excellent works, and cultivate their own aesthetic abilities from their sensibility [2]. There are many advantages of outstanding dance works that are worthy of learning and referencing. When students appreciate dance works, they can learn from their outstanding aspects in an imperceptible way, so that college students not only can have a better aesthetic ability, but also lay a theoretical foundation for their dance creation and performances in the future. What's more, this method will help cultivate dance students' imagination, comprehension and innovation. These foundations are the only way to become outstanding dance students, and this can help students form their own unique views on the works in the future course.

Students majoring in dance in colleges and universities need to accumulate more knowledge in their study and strengthen the study of dance related professional knowledge. Dance is not just an artistic expression, it can express a variety of artistic forms, so an excellent dance work is a form of art that the school brings together and then presents it through dance and music. This can not only bring all forms of enjoyment to the audience, but also touch the hearts of the audience and infect the audience from the bottom of the heart [3]. Therefore, when 
students majoring in dance in colleges and universities are studying, they need not only to study superficial theoretical knowledge, but also to strengthen the study and understanding of music knowledge. Only by integrating all knowledge can we ensure that dance has a more profound impact and that dance can spread further.

Dance performance not only needs a solid foundation of college dance study, but also needs to be more perfect integration with the stage. It is also necessary to take into account the surrounding environment and other supporting objects when performing the dance. It is only after the perfect combination of all that can truly express the effect that the dance works want to present. Dance works and art have a continuous relationship, when design dance, we should appreciate it from the perspective of art, such a dance can be more harmonious.

\section{Strengthen the Training of Dance Students' Practical Ability}

\subsection{Set up the Practical Teaching Link Reasonably}

"Carry out quality-oriented education in an all-round way, deepen comprehensive reform in the field of education, focus on improving the education quality, and cultivate students' spirit of innovation." The report of the 18th National Congress shows that under the guidance of the scientific concept of development, the scientific development of education must be people-oriented, carry out quality-oriented education in an all-round way, and promote the comprehensive development of students. With the rapid development of higher education in China, the number of teachers in colleges and universities is expanding, especially the number of young teachers. According to data released by the Ministry of Education in 2017, young teachers under the age of 40 make up more than 60 percent of the total number of teachers in colleges and universities. It can be seen that young teachers have become the main force of the faculty of colleges and universities. Teachers are the inheritors of human civilization. Only with high-level teachers can they have high-quality education and promote the faster and better development of education in China [4].

When it refers to the current program of training dance students, China lacks students who are majored in social dance training and mass literature and art. Students are not compulsively asked to have high grades, but are required to have strong specialty and there are few students can meet the requirements. Social dance talents are scarce in the society and it's the first employment choice of dance students. The colleges and universities need to pay attention to the fact that students are reluctant to work on public arts. The main reform measurements of the training program is helping students get more opportunities to put the theory into practice by contacting with related companies, which aims to help students learn from enterprises and improve their skills. In addition, the teachers also need to instruct students to practice during semesters. Students 
have the responsibilities to complete their practice according to teachers' requirements and the make comments by themselves. Finally, the school also needs to ensure that the dance students completed their dance performance by exerting their ability, ensuring that students can enhance their dance abilities by practice, and ultimately ensure that students can better master the relevant knowledge. Only the teachers who are enthusiastic about education industry can realize the great significance of the education work, can they be deeply attracted by the pleasure of the education work itself, can they face their own social responsibility and social task positively, and take education as the pleasure; Can self-consciously strengthen their self-cultivation, constantly improve themselves and gain a lot from educational [5].

\subsection{Colleges and Universities Need to Place Emphases on the Dance Practice Teaching Activity}

Dance teachers need to increase students' practical ability, which can improve the quality of dance teaching. The colleges and universities have the following two ways. Considering its situation, colleges can hire professional staff to guide and lecture on the students' dance, so that students can find their distance in the practical ability and the differences between the ideal and the actual. Colleges and universities also can employ well-known professional teams to school, so that students have opportunity to communicate with professional dance groups who own lots of practice knowledge. The professional dance teams can help students increase practical experience by sharing their opinions face-to-face.

Colleges and universities need to formulate a set of teaching methods and systems suitable for the development of the school according to their own actual conditions, so as to ensure that dance students can learn more knowledge in teaching, and the factual and realistic teaching system is also a trend in college dance education [6]. Teachers need to regularly carry out dance performances in accordance with the respective situations of students so that all students can utilize their own knowledge. Teachers need to carry out strict requirements on students, continue to enlighten students' dance learning advantages, and improve students' professional ability in the course of teaching activity. Statistic shows that only dance students combine their professional knowledge with practice can they improve their abilities and have a good foundation for future study.

Colleges and universities should not choose a single type of dance when conducting dance teaching. They need to develop a variety of dance types according to the actual situation of the students and the strength of the school to improve the comprehensive quality of the students. Not all students are fit in the same type of dance. But some common points can be found in different types of dance, although dance types distinguish themselves from each other with different learning techniques and learning methods, they are beneficial for students to improve their comprehensive ability and set a solid foundation for their subsequent development. 


\section{Building Elaborately Designed Practical Dance Courses}

\subsection{Coordinating the Construction of Major Courses and Elective Courses}

The construction of curriculum is an important part of the dance field. The Academic Affairs Office of the university needs to formulate the curriculum according to its fact, the documents issued by the Ministry of Education and the personnel training program of the school should change or discard the unpractical courses, and develop some courses with characteristics of the time.

The main courses that all colleges need to carry out during its teaching program including basic skills, basic skills for dance, choreography and dance appreciation. However, when it refers to the construction of elective courses, it is necessary to consider the characteristics of the school and the future of the dance students that the college wants to develop in the course of elective courses.

\subsection{Promoting the Construction of High-Quality Dance Courses in Colleges}

With a large number of colleges carrying out the program of establishing excellent courses, their course system and teaching content will be optimized to different degrees. At the same time, the related teachers also need to pay attention to the dynamics of dance students and reform and innovate the courses constantly. The construction of the excellent courses requires teachers to encourage students to create by themselves and schools also need to hire more professional teachers to guide students and generate the best teaching resources. Colleges can discuss the construction methods and practical operations of the excellent courses to ensure the program will allow the resources to be shared among all schools so that more students can learn more knowledge during their free time, which aims to improve the learning ability and quality of dance students.

\section{Conclusion}

The construction of spiritual civilization in the new period also needs a large number of excellent dance talents. When dance professionals make the talent training plan, the construction and development plan of the training objectives are needed to be considered. Through the research and discussion on the cultivation of dance talents, we can make clear the goal of training, actively explore scientific mode of talent training, and finally ensure standardized implementation of the talent training mode, high-quality talents exported for the society, and a good foundation laid for the construction of national spiritual civilization.

\section{Conflicts of Interest}

The author declares no conflicts of interest regarding the publication of this paper.

\section{References}

[1] Wang, R.J. (2014) Study on the Reform of Training Model for Dance Students in 
College. Nan Feng, No. 33, 42-22.

[2] Liu, H. (2017) The Analysis of the Reform of Training Model for Dance Students in Colleges and Universities. Shen Zhou, No. 35, 123.

[3] Zhou, T.Y. (2016) The Analysis of the Reform of Training Model for Dance Students in Colleges and Universities. Public Literature, No. 5, 256.

[4] Ma, D.X. (2017) Strengthen the Construction of Young Teachers' Ethics in Colleges and Universities. Journal of the Chinese People's Political Consultative Conference, 2017-03-01 (010).

[5] Wang, L.S. and D.L. Zeng. (2016) Exploration of Red Dance Education in Colleges and Universities in the New Period. Youth, No. 11, 205-206.

[6] Gao L.X. (2017) On the Application of Red Cultural Resources in College Dance Creation. Literature Life, No. 12, 94, 98. 